\title{
Chain-extension reactions via insitu capture of the dibromofluoromethide ion with difluoromethylene fluoro-olefins
} Donald J. Burton* and Steven W. Hansen

\author{
Department of Chemistry, University of Iowa, Iowa City, IA 52242, USA \\ E-mail: donald-burton@uiowa.edu
}

\section{Dedicated to Cynthia and Bruce Maryanoff}

\begin{abstract}
The insitu reaction of triphenylphosphine, tribromofluoromethane, and a difluoromethylene olefin successfully allows the capture of the intermediate dibromofluoromethide ion. With fluorinated propenes, the product is an allylic dibromofluoromethyl alkene; with longer chain fluoro-olefins the major product is a 1-bromo-1,3-fluorinated diene derivative. Pentafluoropyridine yields 4-dibromofluoromethyltetrafluoropyridine.
\end{abstract}

Keywords: Dibromofluoromethide ion, fluoro-olefins, fluorodienes, ${ }^{19} \mathrm{~F}$ - NMR spectroscopy, chain-extension

\section{Introduction}

Fluoro-olefins, especially difluoromethylene olefins, react with a wide variety of nucleophiles. ${ }^{1,2}$ In the absence of a proton source, the intermediate carbanion can eliminate fluoride ion to regenerate the double bond (Scheme 1).

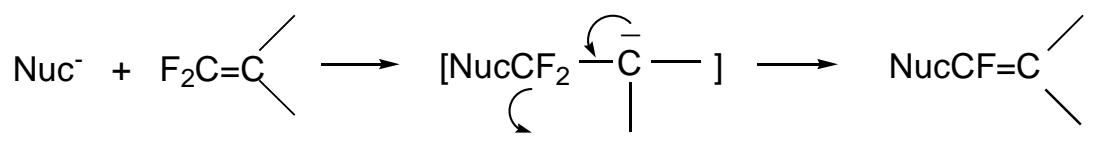

\section{Scheme 1}

If the nucleophile is a carbanion, this process provides a chain extension. Possible side reactions include proton abstraction by the intermediate carbanion (Scheme 2), attack of the intermediate carbanion on another molecule of the olefin (Scheme 3), 


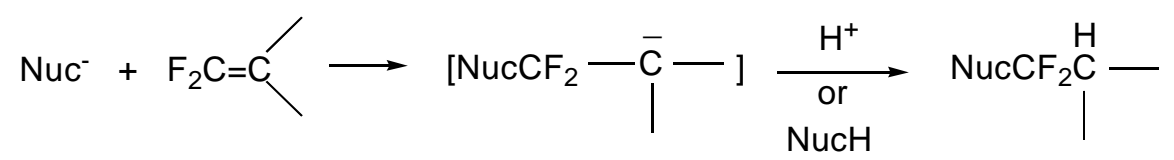

\section{Scheme 2}

which can potentially lead to oligomers or polyenes, and further reaction of the initially formed

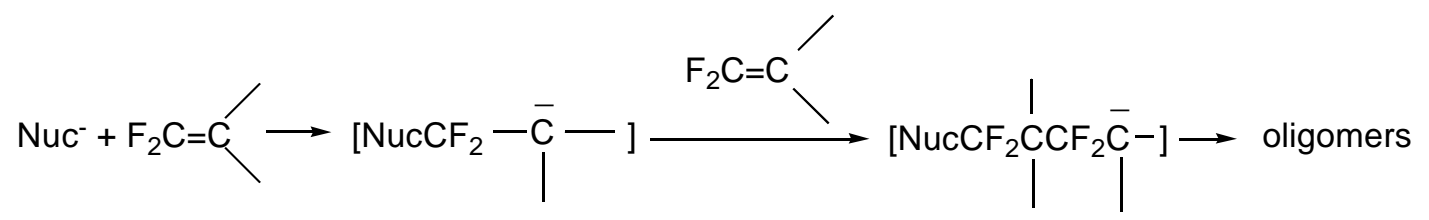

\section{Scheme 3}

product olefin with a second equivalent of the nucleophile (Scheme 4). Nevertheless, there are many examples which demonstrate that the substitution process is a viable route to chainextended fluoro-olefins.

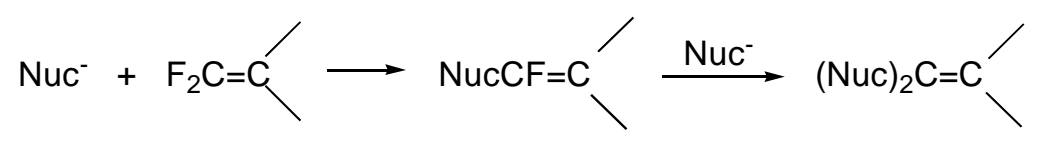

\section{Scheme 4}

A chain-extension reaction occurred when perfluoroisobutene or hexafluoropropene was treated with sodio-methylmalonic ester (Equation 1 ). ${ }^{3}$ Phosphonium ylides can also be viewed as stabilized carbon nucleophiles and have been demonstrated to react with fluoro-olefins (Scheme 5). ${ }^{4,5}$ Fluorine-containing ylides behave similarly (Scheme 6). ${ }^{6,7}$

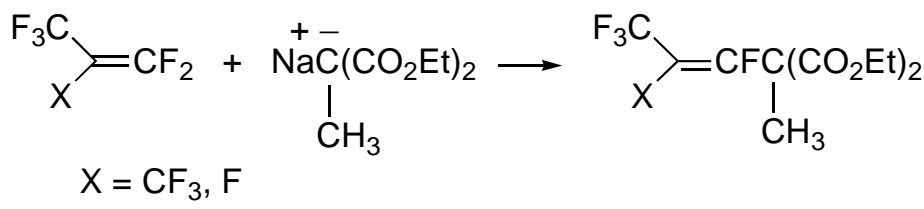

Chain-extended phosphonium salts gave fluorinated dienes as the major product (Scheme 6) 


$$
\begin{aligned}
& \mathrm{Ph}_{3} \stackrel{+}{\mathrm{P}} \overline{\mathrm{C}}\left(\mathrm{CH}_{3}\right)_{2}+\mathrm{F}_{2} \mathrm{C}=\mathrm{CFCF}_{3} \underset{89 \%}{\stackrel{\mathrm{RT}}{3 \mathrm{~h}}} \stackrel{\left[\mathrm{Ph}_{3} \mathrm{P}\right.}{\left.\stackrel{+}{(}\left(\mathrm{CH}_{3}\right)_{2}\right] \mathrm{F}^{-}} \\
& 94 \% \mid \begin{array}{l}
\mathrm{MeOH} / \mathrm{KF} / \mathrm{TG} \\
60^{\circ} \mathrm{C} / 4 \mathrm{~h}
\end{array} \\
& \left.\left(\mathrm{CH}_{3}\right)_{2} \mathrm{C}=\mathrm{CFCHFCF}_{3}+{ }_{\mathrm{H}_{3} \mathrm{C}}^{\mathrm{H}_{3} \mathrm{C}}\right\rangle=\mathrm{FF}_{\mathrm{F}}^{\mathrm{CF}_{3}}+\left(\mathrm{CH}_{3}\right)_{2} \mathrm{C}=\mathrm{CFCF}=\mathrm{CF}_{2} \\
& \begin{array}{lllll}
62 & : & 20 & ;
\end{array}
\end{aligned}
$$

\section{Scheme 5}

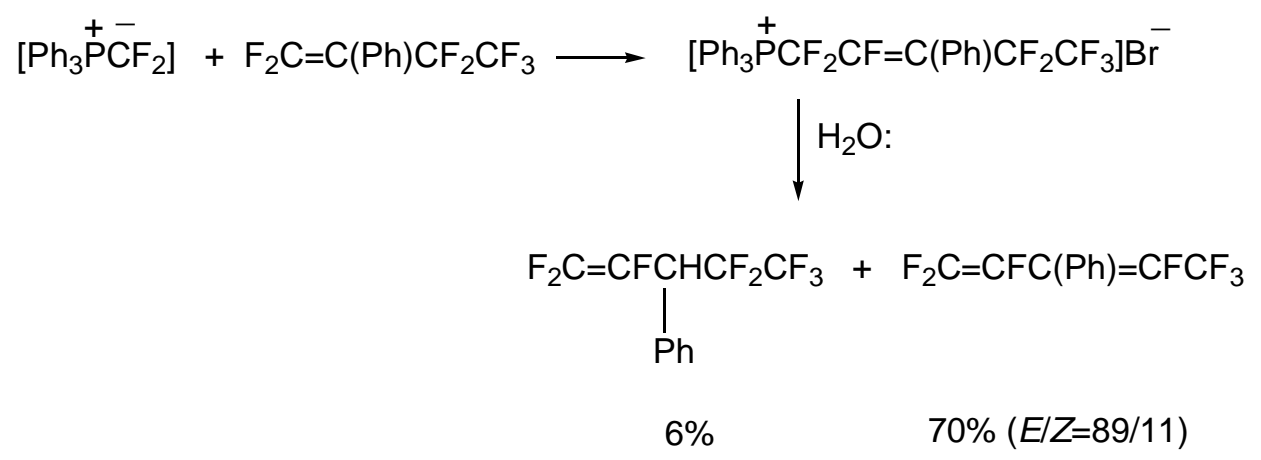

\section{Scheme 6}

If the initial ylide/olefin reaction generated a new difluoromethylene olefin center, the initially formed phosphonium salt could react with a second equivalent of the ylide to produce a bis-phosphonium salt, which on hydrolysis gave a two carbon chain-extended diene product, as illustrated in Scheme $7 .^{7}$ Halofluoromethide ions constitute another class of fluorine-containing

$$
\begin{aligned}
& \mathrm{F}_{2} \mathrm{C}=\mathrm{C}(\mathrm{Ph}) \mathrm{CF}_{2} \mathrm{Cl}+\left[\mathrm{Ph}_{3} \stackrel{+}{\mathrm{PC}} \mathrm{F}_{2} \mathrm{Br}^{\mathrm{Br}} \stackrel{-}{\longrightarrow} \stackrel{\mathrm{Cd}}{\longrightarrow}\left[\mathrm{Ph}_{3} \stackrel{+}{\mathrm{P}} \mathrm{CF}_{2} \mathrm{CF}_{2} \mathrm{C}(\mathrm{Ph})=\mathrm{CF}_{2}\right] \mathrm{Br}^{-}\right. \\
& \text {A }
\end{aligned}
$$

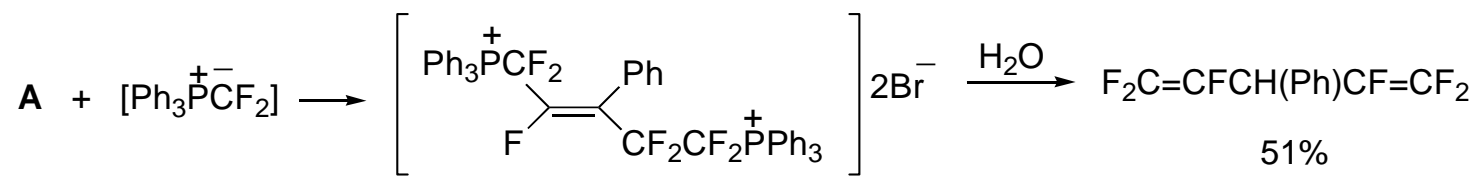

\section{Scheme 7}


carbon nucleophiles which can readily react with fluoro-olefins. Chlorodifluoromethide ion $\mathbf{1}$ (or possibly a complex with HMPA) was successfully trapped by Wheaton with 2phenylpentafluoropropene 2, as illustrated in Equation 2. ${ }^{8}$ Bromodifluoromethide ion 3, generated in an analogous manner from $\mathrm{BrCF}_{2} \mathrm{CO}_{2} \mathrm{CH}_{3}$ gave $\mathrm{BrCF}_{2} \mathrm{CF}=\mathrm{C}(\mathrm{Ph}) \mathrm{CF}_{3}$ in $25 \%$ yield from the olefin 2-pentafluoropropene, 2.

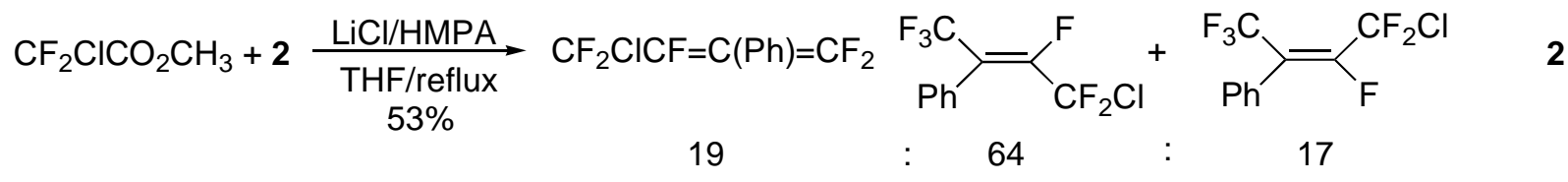

The bromodifluoromethide ion 3 was also formed by treatment of bromodifluoromethyltriphenylphosphonium bromide $\mathbf{4}$ with KF and again trapped with olefin 2 (Eq. 3). ${ }^{9}$ Thus, there is reasonable evidence that halofluoromethide ions can be trapped by appropriate fluoro-olefins to yield chain-extended olefins.

$$
\left[\mathrm{Ph}_{3} \stackrel{+}{\mathrm{P} C F_{2}} \mathrm{Br}_{\mathrm{B}} \overline{\mathrm{r}}+\mathrm{F}_{2} \mathrm{C}=\mathrm{C}(\mathrm{Ph}) \mathrm{CF}_{3} \underset{75 \%}{\stackrel{\mathrm{KF}}{\longrightarrow}} \quad \mathrm{BrCF}_{2} \mathrm{CF}=\mathrm{C}(\mathrm{Ph}) \mathrm{CF}_{3} \quad \mathrm{E} / \mathrm{Z}=1 / 4\right.
$$

\section{Results and Discussion}

An initial attempt was made to carry out the chain-extension of olefin 2 with $\mathrm{LiCFBr}_{2}$, generated from n-BuLi and $\mathrm{CFBr}_{3} 5$ in $\mathrm{THF} /$ hexane at $-110^{\circ} \mathrm{C} .^{10}$ Subsequent addition of olefin 2 and analysis of the reaction mixture (after warming to RT) gave no evidence for any reaction of olefin 2. Apparently, $\mathrm{LiCFBr}_{2}$ decomposed faster than reaction with the olefin.

Tertiary phosphines react with fluorotrihalomethanes to form phosphonium salts. ${ }^{11}$ The mechanism of phosphonium salt formation is not an $\mathrm{SN}_{2}$ process, but involves halophilic attack on the halogen (other than fluorine) by the tertiary phosphines to form an ion-pair, followed by recombination of the ion-pair, as illustrated in Scheme 8. This mechanistic interpretation is supported by the observation that only the phosphonium salt is obtained when dry solvent is utilized (Path A); but the product is $\mathrm{CFHX}_{2}$ when water or ethanol are present (Path B).

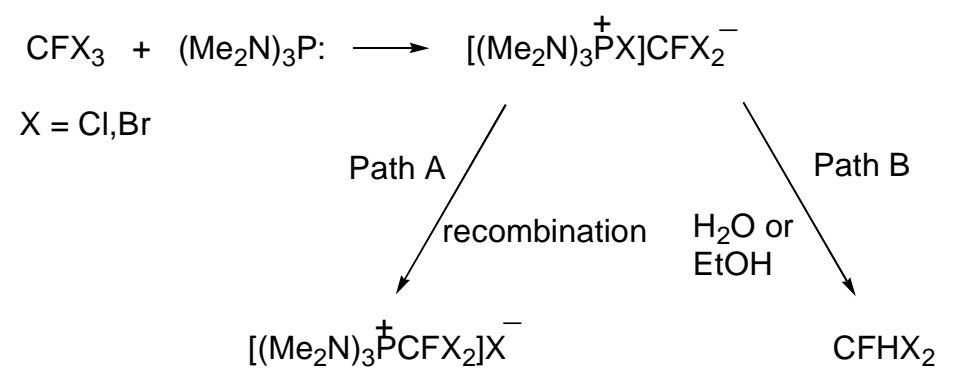

Scheme 8 
The phosphonium salt is not hydrolyzed to $\mathrm{CFHX}_{2}$ by $\mathrm{H}_{2} \mathrm{O}$ or EtOH. ${ }^{11-13}$ Since the dibromofluoromethide ion 6 could be generated readily (from 5 ) by the process described in Scheme 8, it was of interest to determine whether the carbanion $\mathbf{6}$ generated in this manner could be captured by a fluoro-olefin faster than recombination of the ion-pair to form the phosphonium salt. The dibromofluoromethide ion $\mathbf{6}$ differs from chlorodifluoromethide $\mathbf{1}$ and bromodifluoromethide $\mathbf{3}$ in two important ways. Carbanions $\mathbf{1}$ and $\mathbf{3}$ are unstable and rapidly lose halide ion to form difluorocarbene, Equation 4. Although this process was initially proposed to be irreversible, subsequent work demonstrated that this $\alpha$-halide elimination reaction was reversible. $^{14-15}$

$$
\begin{aligned}
& {\left[\mathrm{CF}_{2} \mathrm{X}\right]^{-} \rightleftharpoons\left[: \mathrm{CF}_{2}\right]+\mathrm{X}^{-}} \\
& \mathrm{X}=\mathrm{Cl}, \mathrm{Br}
\end{aligned}
$$

It has also been demonstrated that dibromofluoromethide carbanion $\mathbf{6}$ loses halide in a irreversible process. ${ }^{16}$ Secondly, it is known that halogens stabilize carbanions in the order $\mathrm{I}^{-} \sim$ $\mathrm{Br}^{-}>\mathrm{Cl}^{-}>\mathrm{F}^{-}$, but that dihalocarbenes are stabilized by halogens in the reverse order: $\mathrm{F}>\mathrm{Cl}>\mathrm{Br}$ $>$ I. $^{17}$ Thus, it seemed reasonable that carbanion 6 should have a better opportunity to be captured by a fluoro-olefin than carbanions 1 or 3 .

It is also been demonstrated that the initially formed phosphonium salt (from $\mathrm{CFBr}_{3}$ 5) reacts with a second equivalent of tertiary phosphine to produce the bromofluoromethylene ylide and a dihalophosphorane, as illustrated in Equation 5. ${ }^{11,13}$ Thus, an alternative mechanism might involve attack by the ylide on the fluoro-olefin, as shown in Scheme 9.

$$
\left[\mathrm{Ph}_{3} \stackrel{+}{\mathrm{P}} \mathrm{CFBr}{ }_{2}\right] \mathrm{Br}^{-}+\mathrm{Ph}_{3} \mathrm{P}:=\left[\mathrm{Ph}_{3} \stackrel{+}{\mathrm{P}} \mathrm{C} \mathrm{FBr}\right]+\mathrm{Ph}_{3} \mathrm{PBr}_{2}
$$

However, when 2-phenylpentafluoropropene 2 was present during the addition of $\mathrm{CFBr}_{3} 5$ to a solution of $\mathrm{Ph}_{3} \mathrm{P}: 7,92 \%$ of $(\mathrm{Z})-\mathrm{CFBr}_{2} \mathrm{CF}=\mathrm{C}(\mathrm{Ph}) \mathrm{CF}_{3}$ was observed via ${ }^{19} \mathrm{~F}$ NMR analysis of the reaction mixture.

$$
\begin{gathered}
{\left[\mathrm{Ph}_{3} \stackrel{+}{\mathrm{P}} \overline{\mathrm{C}} \mathrm{FBr}\right]+2 \stackrel{\mathrm{THF}}{\longrightarrow}\left[\mathrm{Ph}_{3} \stackrel{+}{\mathrm{P} C F B r C F}=\mathrm{C}(\mathrm{Ph}) \mathrm{CF}_{3}\right] \mathrm{F}} \\
\qquad \overline{\mathrm{C}} \mathrm{FBr}-\mathrm{CF}=\mathrm{C}(\mathrm{Ph}) \mathrm{CF}_{3} \mathrm{H}_{2} \mathrm{O}
\end{gathered}
$$

\section{Scheme 9}


Apparently, carbanion $\mathbf{6}$ was trapped faster by olefin 2 before recombination of the ion-pair. Thus, this alternative mechanism either does not compete for fluoro-olefin or is only a minor pathway. $^{18}$

The success of the trapping of carbanion $\mathbf{6}$ depended on the presence of a terminal difluoromethylene group in the olefin, and a carbanion-stabilizing group(s) on the $\beta$-carbon of the fluoro-olefin. But it was also important that the fluoro-olefin not be so reactive that it would react directly with $\mathrm{Ph}_{3} \mathrm{P} \quad$ 7. $^{19}$ For example, $\quad \mathrm{F}_{2} \mathrm{C}=\mathrm{C}(\mathrm{Ph}) \mathrm{CF}_{2} \mathrm{Cl}, \quad \mathrm{F}_{2} \mathrm{C}=\mathrm{CFCF} \mathrm{Cl}_{2}$. $\mathrm{F}_{2} \mathrm{C}=\mathrm{CFC}\left(\mathrm{CF}_{3}\right)=\mathrm{C}\left(\mathrm{CF}_{3}\right) \mathrm{H}$ and perfluorocyclobutene ${ }^{20}$ reacted directly with $\mathrm{Ph}_{3} \mathrm{P}$ and failed to give chain-extended product.

The fluoro-ethylenes, iodo- and bromo-trifluoro-ethylenes, did not react at all at RT, and $\mathrm{F}_{2} \mathrm{C}=\mathrm{CCl}_{2}$ gave only a $16 \%$ yield of $\mathrm{CFBr}_{2} \mathrm{CF}=\mathrm{CCl}_{2}$ (as determined by ${ }^{19} \mathrm{~F}-\mathrm{NMR}$ ). However, hexafluoropropene 8 gave an $80 \%$ isolated yield of $(E)$ - and $(Z)-C_{F B r} C F=\mathrm{CFCF}_{3}(E / Z=89 / 11)$. Similarly, the olefin 2 gave a $62 \%$ isolated yield of $(Z)-\mathrm{CFBr}_{2} \mathrm{CF}=\mathrm{C}(\mathrm{Ph}) \mathrm{CF}_{3}$ and 2-(pmethoxyphenyl)pentafluoropropene gave a $90 \%$ yield of

(Z)- $\mathrm{CFBr}_{2} \mathrm{CF}=\mathrm{C}\left(\mathrm{CF}_{3}\right) \mathrm{C}_{6} \mathrm{H}_{4} \mathrm{OCH}_{3}-\mathrm{p}$ ) (as determined by ${ }^{19} \mathrm{~F}$ - NMR). Table 1 summarizes these results. Longer chain analogs of olefin 2 reacted with 7 and 5 to give 1-bromo-1,3-diene products, as illustrated in Equation 6, cf. to Table 1, entries 4-6. With perfluoro-1-olefins, the isolated product was also the (1-Z,3-E)-1-bromo-1,3-diene derivative and not the simple addition-elimination product, as shown with F-1-heptene in Equation 7.

$$
\begin{aligned}
& \mathrm{Ph}_{3} \mathrm{P}+\mathrm{CFBr}_{3}+\mathrm{F}_{2} \mathrm{C}=\mathrm{C}(\mathrm{Ph}) \mathrm{CF}_{2} \mathrm{CF}_{3} \frac{\mathrm{TG}}{82 \%} \quad(E, Z: Z, Z)-\mathrm{CFBr}=\mathrm{CFC}(\mathrm{Ph})=\mathrm{CFCF}_{3} \quad 6 \\
& \mathrm{Ph}_{3} \mathrm{P}+\mathrm{CFBr}_{3}+\mathrm{F}_{2} \mathrm{C}=\mathrm{C}\left(\mathrm{CF}_{2}\right)_{4} \mathrm{CF}_{3} \frac{\mathrm{TG}}{46 \%}
\end{aligned}
$$

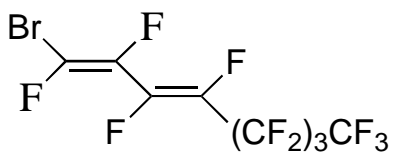

Similar results were obtained with F-1-pentene and F-1-nonene, (see Table 1, entries 7-9). Mechanistically, the bromodienes can be rationalized via further reaction of the initially formed addition-elimination product(s) ${ }^{21}$ with either $\mathrm{Ph}_{3} \mathrm{P} 7$ or $\mathrm{CFBr}_{2}^{-}$, as illustrated in Scheme 10. The stereochemistry of the dienes was determined from ${ }^{19} \mathrm{~F}$ - NMR coupling constants, and the $(E)$ - and $(Z)-{ }^{3} \mathrm{~J}_{\mathrm{FF}}$ are readily distinguished by the magnitude of the vinyl coupling constants. ${ }^{22}$ 


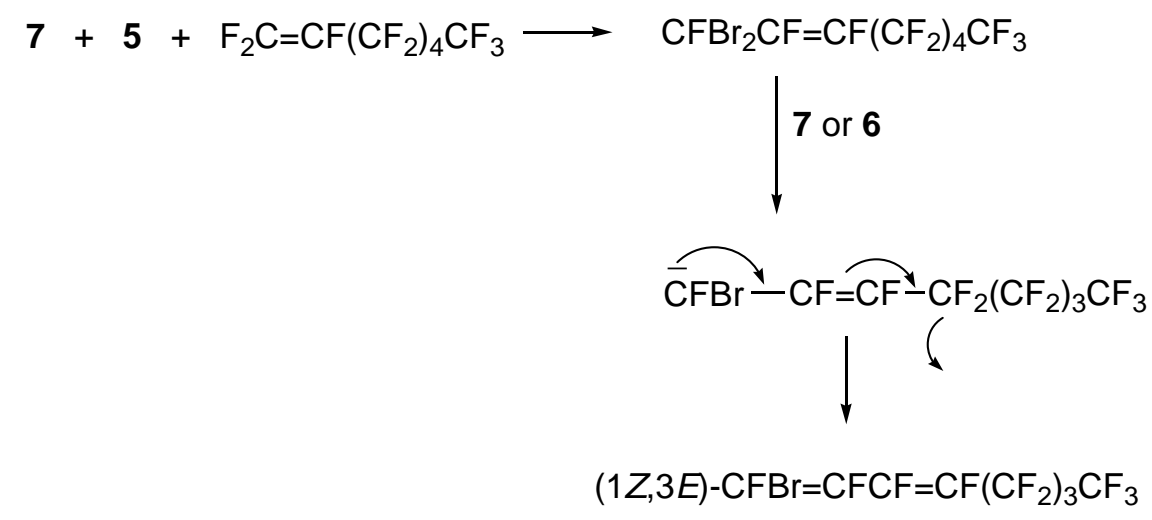

\section{Scheme 10}

The stereochemistry of the internal double bond of $\mathrm{CFBr}=\mathrm{CFC}(\mathrm{Ph})=\mathrm{CFCF}_{3}$ and similar compounds was determined from the following long range coupling constants. ${ }^{6,23-24}$

Table 1. Yields of $\mathrm{CFBr}_{2}$ olefins and 1-bromo-1,3-dienes.

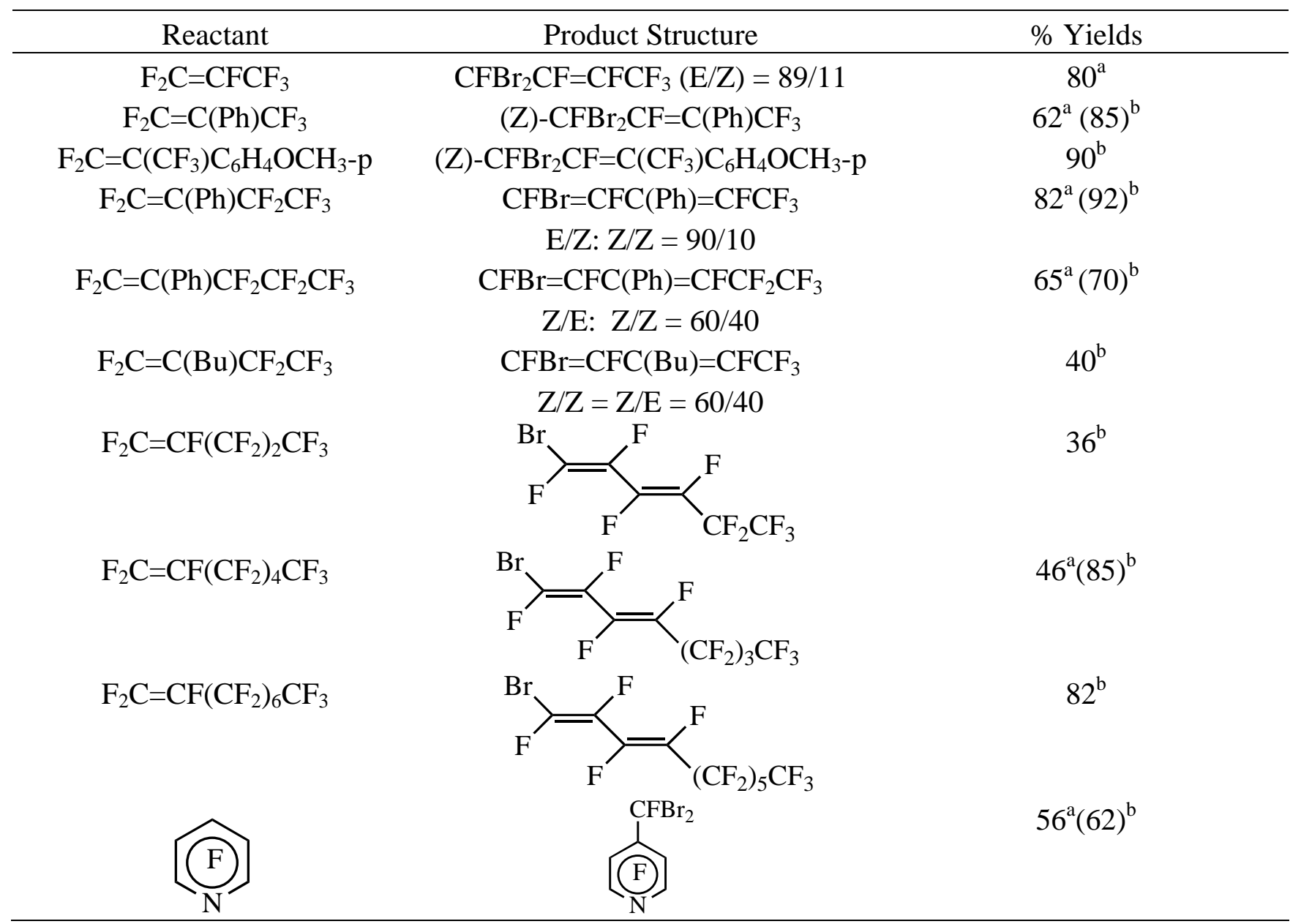

isolated yield. ${ }^{\mathrm{b}}{ }^{19} \mathrm{~F}$ NMR yield vs. $\mathrm{PhCF}_{3}$. 


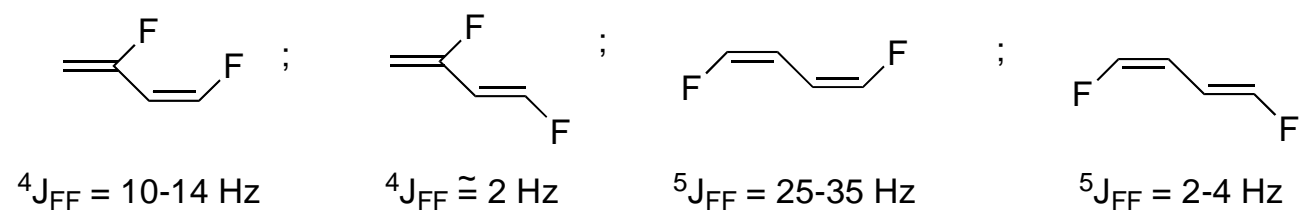

As with chlorodifluoromethide 1, and bromodifluoromethide 3, dibromofluoromethide 6 can be readily trapped with pentafluoropyridine, Equation 8.

$$
\mathrm{Ph}_{3} \mathrm{P}+\mathrm{CFBr}_{3}+\underset{\mathrm{N}}{\widehat{\mathrm{F}}} \frac{\mathrm{TG}}{2 \text { days }} \underset{\substack{\mathrm{RT} \\ \mathrm{N}}}{\stackrel{\mathrm{F}}{\mathrm{N}}}
$$

8

\section{Conclusions}

When triphenylphosphine and tribromofluoromethene are allowed to react in the presence of an appropriate difluoromethylene fluoro-olefin, the intermediate dibromofluoromethide ion is captured by the fluoro-olefin. With hexafluoropropene and 2-substituted trifluoropropenes, the addition-elimination product is formed. With longer chain 2-substituted difluoromethylene olefins, the 1-bromo-1,3-substituted dienes are the major product(s). Similar diene formation is observed with perfluoro-1-alkenes. The capture of the dibromofluoromethide ion results in a chain-extension process. With pentafluoropyridine, 4-dibromofluoromethyltetrafluoropyridine is formed in moderate yield.

\section{Experimental Section}

General. RT denotes room temperature. ${ }^{1} \mathrm{H}$ - NMR spectra were recorded on a Jeol FX90Q spectrometer in $\mathrm{CDCl}_{3}$. Chemical shifts are in ppm relative to internal TMS. ${ }^{19} \mathrm{~F}-\mathrm{NMR}$ spectra were recorded either on a Varian HA-100 (CW) or Jeol FX90Q (FT) spectrometer. Chemical shifts are given in ppm upfield from internal $\mathrm{CFCl}_{3}$, and were generally recorded in $\mathrm{CDCl}_{3}$, neat or triglyme (TG). ${ }^{13} \mathrm{C}$ NMR spectra were recorded on a Bruker HX-90E or JEOL FX90Q spectrometer, with chemical shifts reported in ppm relative to TMS. Infrared spectra were recorded for liquid films between sodium chloride plates on a Beckman Accu Lab 8 instrument. Low resolution mass spectra were recorded on a Hitachi-Perkin Elmer RMU-6E mass spectrometer or a Hewlett-Packard 5985 GC/MS system at $70 \mathrm{eV}$. High resolution mass spectra were obtained from the Midwest Center for Mass Spectrometry at the University of Nebraska, Lincoln, NE. GLPC analyses were carried out on either a Hewlett-Packard 5840A or an F \& M 720 instrument with columns packed with OV-101, SE-30 or Carbowax. 
Materials. Triglyme (TG) and tetrahydrofuran (THF) were distilled from sodium benzophenone ketyl. Fluoroethylenes and hexafluoropropene were obtained from commercial sources and used as received. 2-phenylpentafluoropropene and substituted 2-phenyl difluoromethylene olefins were prepared by the literature procedure. ${ }^{25,26}$ F-1-pentene, F-1-heptene and F-1-nonene were prepared by the literature procedure. ${ }^{27}$ Tribromofluoromethane was prepared by the literature procedure. $^{28}$ Triphenylphosphine, pentafluoropyridine, potassium fluoride, and n-BuL/hexane were purchased from commercial sources.

(Z)-1,1-dibromo-3-phenyl-1,2,4,4,4-pentafluoro-2-butene. A 3-neck, $250 \mathrm{ml}$ flask was equipped with a septum port, a nitrogen inlet tee and a magnetic stir bar. Triphenylphosphine $\mathrm{PhP}_{3} 7$ (22 g, $\left.84 \mathrm{mmol}\right)$ and THF (100 ml) were added to the flask; then $\mathrm{CFBr}_{3} 5$ (21.6 g, $80 \mathrm{mmol}$ ) and 2-phenylpentafluoropropene $2(10.4 \mathrm{~g}, 50 \mathrm{mmol})$ were added via syringe. After stirring at RT overnight, ${ }^{19} \mathrm{~F}$ NMR analysis showed a significant amount of unreacted 2, so additional 7 (17.8 g, $67 \mathrm{mmol})$ and 5 (13.8 g, $51 \mathrm{mmol})$ were added and the reaction mixture stirred an additional $8 \mathrm{~h}$ at RT. The reaction mixture was pressure filtered under $\mathrm{N}_{2}$ through a fritted glass filter (medium frit), the solids rinsed with $15 \mathrm{ml}$ THF. Most of the THF was removed by vacuum distillation, the distillation continued at $0.3 \mathrm{~mm} \mathrm{Hg}$ (oil bath temp. of $160^{\circ} \mathrm{C}$ ). The oily distillate was fractionally distilled under vacuum to give $11.8 \mathrm{~g}(62 \%)$ of $(\mathrm{Z})$ $\mathrm{CFBr}_{2} \mathrm{CF}=\mathrm{C}(\mathrm{Ph}) \mathrm{CF}_{3}$, bp $82^{\circ} \mathrm{C} / 0.5 \mathrm{~mm} \mathrm{Hg}$. GC/MS m/z (relative intensity): $382(0.9 \mathrm{M}+4)$, 380 (2.0, M + 2), 378 (1.0, M), 220 (18, M-2Br), 151 (100, M-2Br, CF $) . I R\left(\mathrm{~cm}^{-1}\right): 1680$ (s), 1496 (m), 1449 (m), 1332 (s), 1240-1100 (vs), 981 (m). ${ }^{19} \mathrm{~F}$ NMR (ppm, TG): $\delta-60.5$ (d, ${ }^{4} J_{\mathrm{FF}}=$ $24 \mathrm{~Hz}),-63.6\left(\mathrm{~d},{ }^{3} J_{\mathrm{FF}}=38 \mathrm{~Hz}\right),-101.0\left(\mathrm{dq},{ }^{3} J_{\mathrm{FF}}=38 \mathrm{~Hz},{ }^{4} J_{\mathrm{FF}}=24 \mathrm{~Hz}\right) .{ }^{1} \mathrm{H}$ NMR (ppm. $\left.\mathrm{CDCl}_{3}\right)$ : $\delta 7.40(\mathrm{~m}) .{ }^{13} \mathrm{C}$ NMR (ppm, neat): 80.8 (d, $\left.{ }^{1} J_{\mathrm{CF}}=322.5 \mathrm{~Hz}\right), 112.2\left(\mathrm{dq},{ }^{2} J_{\mathrm{CF}}=33.4 \mathrm{~Hz},{ }^{2} J_{\mathrm{CF}}=\right.$ $10.0 \mathrm{~Hz}), 121.9$ (q, $\left.{ }^{1} J_{\mathrm{CF}}=276.3 \mathrm{~Hz}\right), 126.9$ (s), 128.1 (s), $128.6(\mathrm{~s}), 129.8$ (s), 154.7 (ddq, ${ }^{1} J_{\mathrm{CF}}=$ $\left.273.2 \mathrm{~Hz},{ }^{2} J_{\mathrm{CF}}=23.9 \mathrm{~Hz},{ }^{3} J_{\mathrm{CF}}=2.9 \mathrm{~Hz}\right)$.

(E)- and (Z)-1,1-dibromo-1,2,3,4,4,4-hexafluoro-2-butenes. A three-neck 1-liter flask was equipped with a septum port, a Dry Ice/isopropyl alcohol-cooled cold finger condenser, thermometer and magnetic stir bar. $\mathrm{Ph}_{3} \mathrm{P} 7(78.7 \mathrm{~g}, 300 \mathrm{mmol}$ ) was dissolved (with stirring) in TG (340 ml) at RT. CFBr 5 (78.8 g, $291 \mathrm{mmol}$ ) was added via syringe followed by 8 (19.5 g, $130 \mathrm{mmol}$ ) via the cold finger condenser. The reaction mixture was stirred overnight at RT, then vacuum distilled $\left(\sim 60^{\circ} \mathrm{C} / 0.2 \mathrm{~mm} \mathrm{Hg}\right)$. The distillate was $\sim$ equal amounts of $\mathrm{CFBr}_{2} \mathrm{CF}=\mathrm{CFCF}_{3}$ and 5 . These two components could not be separated by spinning band distillation; a constant boiling $\left(93^{\circ} \mathrm{C}\right)$ mixture was obtained. However, $\mathrm{CFBr}_{3}$ could be removed by selective fluorination. The constant boiling mixture was added to a $100 \mathrm{ml}$ flask equipped with a Claisen head, a mechanical stirrer, and a water-cooled condenser topped by a nitrogen inlet tee. $\mathrm{SbF}_{3}$ (49.7 g, $278 \mathrm{mmol})$ and $\mathrm{Br}_{2}(4.4 \mathrm{~g}, 27.5 \mathrm{mmol})$ were added and the mixture refluxed for $40 \mathrm{~h}$. The reaction mixture was then distilled under nitrogen at atmospheric pressure (bp $105^{\circ} \mathrm{C}$ ). The distillate was washed with $5 \%$ tartaric acid $(2 \times 25 \mathrm{ml}), \mathrm{H}_{2} \mathrm{O}(25 \mathrm{ml})$ to give a clear colorless liquid, which was dried over 4Å molecular sieves, then flash distilled (RT @ 02 mm Hg) to give $33.5 \mathrm{~g}\left(80 \%\right.$ based on 8) of $\mathrm{CFBr}_{2} \mathrm{CF}=\mathrm{CFCF}_{3}(E / \mathrm{Z}=89 / 11) .{ }^{19} \mathrm{~F} \mathrm{NMR}\left(\mathrm{ppm}, \mathrm{CDCl}_{3}\right)$ : $(E)-$ isomer: $\delta$-80.4 (ddd, ${ }^{5} J_{\mathrm{FF}}=10.8 \mathrm{~Hz},{ }^{3} J_{\mathrm{FF}}=7.4 \mathrm{~Hz},{ }^{4} J_{\mathrm{FF}}=4.0 \mathrm{~Hz}$ ); $-105.3\left(\mathrm{ddq},{ }^{3} J_{\mathrm{FF}}=140.8 \mathrm{~Hz}\right.$, 
$\left.{ }^{3} J_{\mathrm{FF}}=46.9 \mathrm{~Hz},{ }^{4} J_{\mathrm{FF}}=4.0 \mathrm{~Hz}\right) ;-139.9\left(\mathrm{ddq},{ }^{3} J_{\mathrm{FF}}=46.9 \mathrm{~Hz},{ }^{4} J_{\mathrm{FF}}=27.4 \mathrm{~Hz},{ }^{5} J_{\mathrm{FF}}=10.8 \mathrm{~Hz}\right)$; $144.3\left(\mathrm{ddq},{ }^{3} J_{\mathrm{FF}}=140.8 \mathrm{~Hz},{ }^{4} J_{\mathrm{FF}}=27.4 \mathrm{~Hz},{ }^{3} J_{\mathrm{FF}}=7.4 \mathrm{~Hz}\right)$. (Z)-isomer: $\delta-79.5\left(\mathrm{dd},{ }^{3} J_{\mathrm{FF}}=10.6\right.$ $\left.\mathrm{Hz},{ }^{4} J_{\mathrm{FF}}=9.4 \mathrm{~Hz}\right) ;-85.2\left(\mathrm{dd},{ }^{3} J_{\mathrm{FF}}=14.4 \mathrm{~Hz},{ }^{4} J_{\mathrm{FF}}=2.8 \mathrm{~Hz}\right) ;-130.1\left(\mathrm{ddq}{ }^{3} J_{\mathrm{FF}}=26.4 \mathrm{~Hz},{ }^{3} J_{\mathrm{FF}}=\right.$ $\left.14.4 \mathrm{~Hz},{ }^{4} J_{\mathrm{FF}}=9.4 \mathrm{~Hz}\right) ;-132.4\left(\mathrm{ddq},{ }^{3} J_{\mathrm{FF}}=26.4 \mathrm{~Hz},{ }^{3} J_{\mathrm{FF}}=10.6 \mathrm{~Hz},{ }^{4} J_{\mathrm{FF}}=2.8 \mathrm{~Hz}\right) . \quad \mathrm{IR}\left(\mathrm{cm}^{-1}\right)$ : 1702 (s), 1290-1190 (vs), 1128 (s), 1170 (m), 813 (m), 747 (m), 678 (m). HRMS (mixture of isomers): Calc'd for $\mathrm{C}_{4} \mathrm{~F}_{6}{ }^{81} \mathrm{Br}^{79} \mathrm{Br}$ : 321.8250, observed 321.8248 .

(Z)-1,1-dibromo-3-(p-methoxyphenyl)-1,2,4,4,4-pentafluoro-2-butenes. As in the preparation of (Z)-CFBr ${ }_{2} \mathrm{CF}=\mathrm{C}(\mathrm{Ph}) \mathrm{CF}_{3}, \quad 7$ (3.2 g, $\left.12 \mathrm{mmol}\right), \mathrm{CFBr}_{3}(3.26 \mathrm{~g}, 12.0 \mathrm{mmol})$ and $\mathrm{F}_{2} \mathrm{C}=\mathrm{C}\left(\mathrm{CF}_{3}\right) \mathrm{C}_{6} \mathrm{H}_{4} \mathrm{OCH}_{3}-\mathrm{p} \quad(0.95 \mathrm{~g}, 4.0 \mathrm{mmol})$ gave a $90 \%$ yield of $(Z)-$ $\mathrm{CFBr}_{2} \mathrm{CF}=\mathrm{C}\left(\mathrm{CF}_{3}\right) \mathrm{C}_{6} \mathrm{H}_{4} \mathrm{OCH}_{3}-\mathrm{p}$ (as determined by ${ }^{19} \mathrm{~F}-\mathrm{NMR}$ ). The reaction mixture was flash distilled and the flash distillate analyzed by GC/MS and ${ }^{19} \mathrm{~F}$ - NMR spectroscopy. ${ }^{19} \mathrm{~F}$ - NMR (ppm, TG): $\delta-60.4$ (d, ${ }^{4} J_{\mathrm{FF}}=24 \mathrm{~Hz}$ ), $-63.2\left(\mathrm{~d},{ }^{3} J_{\mathrm{FF}}=38 \mathrm{~Hz}\right),-100.4\left(\mathrm{dq},{ }^{3} J_{\mathrm{FF}}=38 \mathrm{~Hz},{ }^{4} J_{\mathrm{FF}}=24\right.$ $\mathrm{Hz}$ ). GC/MS, m/z (relative intensity): 412 (1.6, M+ 4), 410 (3.2, M+2), 408 (1.5, M), 250 (100, $\mathrm{M}-2 \mathrm{Br})$.

(Z:E:Z:Z-1-bromo-3-phenyl-1,2,4,5,5,5-hexafluoropenta-1,3-diene. $\quad \mathrm{Ph}_{3} \mathrm{P} \quad 7 \quad(78.6 \quad \mathrm{~g}$, $300 \mathrm{mmol}$ ), $350 \mathrm{ml} \mathrm{TG}, \mathrm{F}_{2} \mathrm{C}=\mathrm{C}(\mathrm{Ph}) \mathrm{CF}_{2} \mathrm{CF}_{3}$ (25.7 g, $\left.100 \mathrm{mmol}\right)$, and $\mathrm{CFBr}_{3} 5$ (81.3 g, $\left.300 \mathrm{mmol}\right)$ was stirred at RT for $20 \mathrm{~h} .{ }^{19} \mathrm{~F}$ - NMR analysis of the reaction mixture showed complete conversion of the olefin to the diene. Flash distillation $(0.2 \mathrm{~mm} \mathrm{Hg})$ gave two $50 \mathrm{ml}$ fractions containing a mixture of diene and triglyme; each fraction was washed with water to remove tiglyme and the fractions combined. The remaining TG was distilled from the reaction mixture and washed with $350 \mathrm{ml} \mathrm{H}_{2} \mathrm{O}$. The combined organic layers were washed with $2 \times 150 \mathrm{ml} \mathrm{H}_{2} \mathrm{O}$, dried over $\mathrm{MgSO}_{4}$, filtered and vacuum distilled. Unreacted 5 was recovered as a low-boiling fraction. The higher boiling fraction (bp $\sim 40^{\circ} \mathrm{C} / 0.2 \mathrm{~mm} \mathrm{Hg}$ ) was the bromodiene ( $>95 \%$ purity); yield 27.0 g (82\%); Z:E:Z:Z = 90/10. ${ }^{19} \mathrm{~F}$ - NMR (ppm, $\mathrm{CDCl}_{3}$ ): (Z:E)-isomer. $\delta-69.3$ $\left(\mathrm{ddd},{ }^{3} J_{\mathrm{FF}}=9.7 \mathrm{~Hz},{ }^{5} J_{\mathrm{FF}}=4.4 \mathrm{~Hz},{ }^{6} J_{\mathrm{FF}}=4.4 \mathrm{~Hz}\right) ;-112.8\left(\mathrm{dqd},{ }^{3} J_{\mathrm{FF}}=140.9 \mathrm{~Hz},{ }^{6} J_{\mathrm{FF}}=4.4 \mathrm{~Hz}\right.$, ${ }^{5} J_{\mathrm{FF}}=3.1 \mathrm{~Hz}$ ); 119.5 (qdd, ${ }^{3} J_{\mathrm{FF}}=9.7 \mathrm{~Hz},{ }^{4} J_{\mathrm{FF}}=3.5 \mathrm{~Hz},{ }^{5} J_{\mathrm{FF}}=3.1 \mathrm{~Hz}$ ), $-132.4\left(\mathrm{ddq},{ }^{3} J_{\mathrm{FF}}=140.9\right.$ $\left.\mathrm{Hz},{ }^{5} J_{\mathrm{FF}}=4.4 \mathrm{~Hz},{ }^{4} J_{\mathrm{FF}}=3.5 \mathrm{~Hz}\right)$. (Z:Z)-isomer $\delta-65.7\left(\mathrm{ddd},{ }^{3} J_{\mathrm{FF}}=8.8 \mathrm{~Hz},{ }^{5} J_{\mathrm{FF}}=1.9 \mathrm{~Hz},{ }^{6} J_{\mathrm{FF}}=\right.$ $1.0 \mathrm{~Hz}$ ), $-107.1\left(\mathrm{ddq},{ }^{3} J_{\mathrm{FF}}=137.2 \mathrm{~Hz},{ }^{5} J_{\mathrm{FF}}=29.0 \mathrm{~Hz},{ }^{6} J_{\mathrm{FF}}=1.0 \mathrm{~Hz}\right),-113.2\left(\mathrm{ddq},{ }^{5} J_{\mathrm{FF}}=29.0\right.$ $\left.\mathrm{Hz}),{ }^{4} J_{\mathrm{FF}}=10.9 \mathrm{~Hz},{ }^{3} J_{\mathrm{FF}}=8.8 \mathrm{~Hz}\right),-140.1\left(\mathrm{ddq},{ }^{3} J_{\mathrm{FF}}=137.2 \mathrm{~Hz},{ }^{4} J_{\mathrm{FF}}=10.9 \mathrm{~Hz},{ }^{5} J_{\mathrm{FF}}=1.9 \mathrm{~Hz}\right)$. GC/MS, m/z (relative intensity): (mixture): $332\left(3.1,{ }^{81} \mathrm{BrM}^{+}\right), 330\left(3.1,{ }^{79} \mathrm{BrM}^{+}, 251\right.$ (100, M$\mathrm{Br}$ ). HRMS (mixture): Calc'd. For $\mathrm{C}_{11} \mathrm{H}_{5}{ }^{81} \mathrm{BrF}_{6}$ : 331.9459, observed 331.9470; Calc'd for $\mathrm{C}_{11} \mathrm{H}_{5}{ }^{79} \mathrm{BrF}_{6}$ : 329.9479, observed 369.9485.

(Z:E:Z:Z)-1-bromo-3-phenyl-1,2,4,5,5,6,6,6-octafluorohexa-1,3-diene. $\quad \mathrm{Ph}_{3} \mathrm{P} \quad(19.7 \quad \mathrm{~g}$, $75 \mathrm{mmol}), 94 \mathrm{ml}$ triglyme, $\mathrm{CFBr}_{3}(20.3 \mathrm{~g}, 75 \mathrm{mmol})$, and $\mathrm{F}_{2} \mathrm{C}=\mathrm{C}(\mathrm{Ph}) \mathrm{CF}_{2} \mathrm{CF}_{2} \mathrm{CF}_{3}(7.7 \mathrm{~g}$, $25 \mathrm{mmol}$ ) were stirred for $48 \mathrm{~h}$ at RT; then the reaction mixture was distilled under vacuum. The first fraction $\left(3.5 \mathrm{ml}\right.$ ) was mostly 5 ; the second fraction (bp $80^{\circ} \mathrm{C} / 1.2 \mathrm{~mm} \mathrm{Hg}$ ) was mostly triglyme and product. This fraction was washed with $9 \times 100 \mathrm{ml}$ water to remove triglyme. The aqueous washes were extracted with Skelly B (6 x $15 \mathrm{ml})$; the Skelly B was removed by rotary evaporation and the residue combined with the rest of the organic material, dried over $4 \AA$ molecular sieves and vacuum distilled to give $6.2 \mathrm{~g}(65 \%)$ of $\mathrm{CFBr}=\mathrm{CFC}(\mathrm{Ph})=\mathrm{CFCF}_{2} \mathrm{CF}_{3}$, bp 
45ํㅡ/0.2 mm Hg; Z:E: Z:Z = 60/40. ${ }^{19}$ F- NMR (ppm, Neat): (Z:E)-isomer: $\delta$-83.0 (m), -111.7 $\left(\mathrm{dm},{ }^{3} J_{\mathrm{FF}}=144 \mathrm{~Hz}\right),-115.7(\mathrm{~m}),-117.6(\mathrm{~m}),-129.0\left(\mathrm{~d},{ }^{3} J_{\mathrm{FF}}=144 \mathrm{~Hz}\right)$. (Z:Z)-isomer: ${ }^{19} \mathrm{~F}-\mathrm{NMR}$ (ppm, neat): $\delta-82.8(\mathrm{~m}),-102.5\left(\mathrm{dd},{ }^{3} J_{\mathrm{FF}}=139 \mathrm{~Hz},{ }^{5} J_{\mathrm{FF}}=31 \mathrm{~Hz}\right),-109.9\left(\mathrm{dtd},{ }^{5} J_{\mathrm{FF}}=31 \mathrm{~Hz},{ }^{3} J_{\mathrm{FF}}\right.$ $\left.=12 \mathrm{~Hz},{ }^{4} J_{\mathrm{FF}}=10 \mathrm{~Hz}\right),-114.0\left(\mathrm{~d},{ }^{3} J_{\mathrm{FF}}=12 \mathrm{~Hz}\right),-139.5\left(\mathrm{dd},{ }^{3} J_{\mathrm{FF}}=139 \mathrm{~Hz},{ }^{4} J_{\mathrm{FF}}=10 \mathrm{~Hz}\right)$. GC/MS, $m / z$ (relative intensity): $382\left(4.0,{ }^{81} \mathrm{BrM}^{+}\right), 380\left(4.0{ }^{79} \mathrm{BrM}^{+}\right), 301$ (100, M-Br). HRMS (mixture): Calc'd for $\mathrm{C}_{12} \mathrm{H}_{5}{ }^{81} \mathrm{BrF}_{8}$ : 381.9426, observed 381.9441; Calc'd for $\mathrm{C}_{12} \mathrm{H}_{5}{ }^{79} \mathrm{BrF}_{8}$ : 379.9447, observed 379.9440.

(Z:Z:Z:E)1-bromo-3-(n-butyl)-1,2,4,5,5,5-hexafluoropenta-1,3-diene. Similar to the reaction with $\mathrm{F}_{2} \mathrm{C}=(\mathrm{Ph}) \mathrm{CF}_{2} \mathrm{CF}_{3}$, (8.65 g, $\left.33 \mathrm{mmol}\right), 15 \mathrm{ml} \mathrm{TG}, \mathrm{F}_{2} \mathrm{C}=\mathrm{C}(\mathrm{n}-\mathrm{Bu}) \mathrm{CF}_{2} \mathrm{CF}_{3}(7.1 \mathrm{mmol})$ and $\mathrm{CFBr}_{3}\left(7.8 \mathrm{~g}, 29 \mathrm{mmol}\right.$ ) were stirred for 2 weeks at $\mathrm{RT},{ }^{19} \mathrm{~F}-\mathrm{NMR}$ analysis of the reaction mixture indicated that most of the fluoroolefin had been consumed. Integration of the ${ }^{19} \mathrm{~F}-\mathrm{NMR}$ signals of the diene product vs. added $\mathrm{PhCF}_{3}$ indicatd a $40 \%{ }^{19} \mathrm{~F}$ - NMR of the diene product $\mathrm{CFBr}=\mathrm{CF}-\mathrm{C}(\mathrm{n}-\mathrm{Bu})=\mathrm{CFCF}_{3}, Z: Z: Z: E=60: 40$. The reaction mixture was flash distilled, and the flash distillate was evacuated at $\mathrm{RT}$ to remove the product from most of the TG. A pure sample of the diene was isolated by GLPC (SE-30) and analyzed by GC/MS and ${ }^{19} \mathrm{~F}-\mathrm{NMR}$. ${ }^{19} \mathrm{~F}$ - NMR (ppm, TG): (Z:Z)-isomer: $\delta-65.8\left(\mathrm{dm},{ }^{3} J_{\mathrm{FF}}=7 \mathrm{~Hz}\right),-109.0\left(\mathrm{dd},{ }^{3} J_{\mathrm{FF}}=140 \mathrm{~Hz},{ }^{5} J_{\mathrm{FF}}=30 \mathrm{~Hz}\right.$ ), $113.6\left(\mathrm{~d},{ }^{5} J_{\mathrm{FF}}=30 \mathrm{~Hz}\right)-143.5\left(\mathrm{~d},{ }^{3} J_{\mathrm{FF}}=140 \mathrm{~Hz}\right)$. (Z:E)-isomer: $\delta-69.7(\mathrm{~m}),-114.7\left(\mathrm{dm},{ }^{3} J_{\mathrm{FF}}=\right.$ $142 \mathrm{~Hz}$ ), $-121.4(\mathrm{~m}),-136.0\left(\mathrm{~d},{ }^{3} J_{\mathrm{FF}}=142 \mathrm{~Hz}\right.$ ). GC/MS, (mixture) $\mathrm{m} / \mathrm{z}$ (relative intensity): 312 , $\left(2.6,{ }^{81} \mathrm{BrM}^{+}\right), 310\left(2.7,{ }^{79} \mathrm{BrM}^{+}\right), 270\left(97,{ }^{81} \mathrm{BrM}-\left(\mathrm{CH}_{2}\right)_{3}\right), 268\left(100,{ }^{79} \mathrm{BrM}-\left(\mathrm{CH}_{2}\right)_{3}\right)$.

(1-Z,3-E)-1-bromo-1,2,3,4,5,5,6,6,6-nonafluorohexa-1,3-diene. As above, $\mathrm{Ph}_{3} \mathrm{P}$ (16.2 g, $61.7 \mathrm{mmol}), 65 \mathrm{ml}$ THF, F-1-pentene (6.40 g, $21.6 \mathrm{mmol})$ and $\mathrm{CFBr}_{3}(16.3 \mathrm{~g}, 60.3 \mathrm{mmol})$ were mixed at $0^{\circ} \mathrm{C}$; the reaction was warmed to RT and stirred overnight at RT. ${ }^{19} \mathrm{~F}$ - NMR analysis of the reaction mixture indicated a 36\% ${ }^{19} \mathrm{~F}$ - NMR yield of (1-Z,3-E)-1-bromo-nonafluoro-1,3hexadiene. Flash distillation of the reaction mixture gave a distillate that was washed with $3 \mathrm{x}$ $200 \mathrm{ml}$ of water to give $2 \mathrm{ml}$ of a lower layer. The water washings were extracted with $3 \mathrm{x} 10 \mathrm{ml}$ $\mathrm{CH}_{2} \mathrm{Cl}_{2}$. The $\mathrm{CH}_{2} \mathrm{Cl}_{2}$ extracts were combined with the lower layer, dried over $\mathrm{CaCl}_{2}$ then fractionally distilled at atmospheric pressure under $\mathrm{N}_{2}$. The product diene could not be isolated pure by distillation and was obtained as a mixture of THF, diene and $\mathrm{CFBr}_{3}$. A sample of pure diene was isolated by GLPC for spectroscopic analysis. ${ }^{19} \mathrm{~F}-\mathrm{NMR}$ (ppm, THF: $\delta$-84.5 (m), $100.6\left(\mathrm{dm},{ }^{3} J_{\mathrm{FF}}=141 \mathrm{~Hz}\right),-119.7$ (broad d, partial overlap, $\left.{ }^{3} J_{\mathrm{FF}}=141 \mathrm{~Hz}\right),-120.7\left(\mathrm{dm},{ }^{3} J_{\mathrm{FF}}=14\right.$ $\mathrm{Hz}),-152.3\left(\mathrm{dm},{ }^{3} J_{\mathrm{FF}}=138 \mathrm{~Hz}\right),-155.0\left(\mathrm{dm},{ }^{3} J_{\mathrm{FF}}=138 \mathrm{~Hz}\right)$. GC/MS, $m / z$ (relative intensity): 324 (59, ${ }^{81} \mathrm{BrM}^{+}$), 322 (63, ${ }^{79} \mathrm{BrM}^{+}$), 255 (99, $\left.{ }^{81} \mathrm{BrM}_{-} \mathrm{CF}_{3}\right), 253$ (100, 79 BrM-CF $), 243$ (15.7, $\mathrm{M}-\mathrm{Br}), 205$ (25, $\left.{ }^{81} \mathrm{BrM}_{-} \mathrm{CF}_{2} \mathrm{CF}_{3}\right), 203$ (26, $\left.{ }^{79} \mathrm{BrM}_{-} \mathrm{CF}_{2} \mathrm{CF}_{3}\right)$. HRMS: Calc'd for $\mathrm{C}_{6}{ }^{81} \mathrm{BrF}_{9}$ : 323.9019, observed 323.9027; Calc'd for $\mathrm{C}_{6}{ }^{79} \mathrm{BrF}_{9}$ : 321.9039, observed 321.9045.

(1-Z,3-E)-1-bromo-1,2,3,4,5,5,6,6,7,7,8,8,8-tridecafluoro-octa-1,3-diene. Similarly, $\quad \mathrm{Ph}_{3} \mathrm{P}$ (23.6 g, $90 \mathrm{mmol}), 100 \mathrm{ml}$ THF, F-1-heptene (10.5 g, $30 \mathrm{mmol}$, and $\mathrm{CFBr}_{3}$ (24.4 g, $90 \mathrm{mmol}$ ) were stirred at RT for $24 \mathrm{~h}$. Flash distillation of the reaction mixture (under vacuum) gave a distillate, which was washed with 3 x $200 \mathrm{ml}$ water to remove THF. The organic layer was dried over $\mathrm{MgSO}_{4}$, and fractionally distilled through a 6" Vigreaux column to give $5.8 \mathrm{~g}$ (46\%) of (1Z,3-E)-1-bromo-tridecafluoruo-octa-1,3-diene, bp $77^{\circ} \mathrm{C} / 57 \mathrm{~mm} \mathrm{Hg}$ ). Repetition of the reaction 
indicated a ${ }^{19} \mathrm{~F}$ - NMR yield of 85\% diene, ${ }^{19} \mathrm{~F}-\mathrm{NMR}\left(\mathrm{ppm}, \mathrm{CDCl}_{3}\right): \delta-80.9\left(\mathrm{t},{ }^{4} J_{\mathrm{FF}}=10 \mathrm{~Hz}\right)$, $100.9\left(\mathrm{dm},{ }^{3} J_{\mathrm{FF}}=131 \mathrm{~Hz}\right),-117.3(\mathrm{~s}),-122.9\left(\mathrm{dm},{ }^{3} J_{\mathrm{FF}}=131 \mathrm{~Hz}\right),-124.5(\mathrm{~s}),-126.0(\mathrm{~m}),-152.2$ $\left(\mathrm{dm},{ }^{3} J_{\mathrm{FF}}=140 \mathrm{~Hz}\right),-153.8\left(\mathrm{dm},{ }^{3} J_{\mathrm{FF}}=140 \mathrm{~Hz}\right) . \mathrm{GC} / \mathrm{MS}, \mathrm{m} / \mathrm{z}$ (relative intensity): 424 (32.3, ${ }^{81} \mathrm{BrM}^{+}$), 422 (33.0, ${ }^{79} \mathrm{BrM}^{+}$), 343 (21, M-Br), 255 (100, $\left.{ }^{81} \mathrm{BrM}_{-} \mathrm{C}_{3} \mathrm{~F}_{7}\right), 253\left(99.8,{ }^{79} \mathrm{BrM} \mathrm{C}_{3} \mathrm{~F}_{7}\right)$. HRMS: Calc'd for $\mathrm{C}_{8}{ }^{81} \mathrm{BrF}_{13}$ : 423.8955, observed, 423.8954; Calc'd for $\mathrm{C}_{8}{ }^{79} \mathrm{BrF}_{13}$ : 421.8975, observed 421.8976.

\section{(1-Z,3-E)-1-bromo-1,2,3,4,5,5,6,6,7,7,8,8,9,9,10,10,10-heptadecafluoro-deca-1,3-diene.}

Similarly, $\mathrm{Ph}_{3} \mathrm{P}$ (3.2 g, $12 \mathrm{mmol}$ ), $16 \mathrm{ml}$ TG, F-1-nonene (1.8 g, $4 \mathrm{mmol}$ ) and $\mathrm{CFBr}_{3}$ (3.3 g, $12 \mathrm{mmol}$ ) were stirred at RT overnight. ${ }^{19} \mathrm{~F}$ - NMR analysis of the reaction mixture indicated the diene was formed in $82 \%{ }^{19} \mathrm{~F}$ - NMR yield. Flash distillation of the reaction mixture under vacuum $\left(80^{\circ} \mathrm{C} / 0.2 \mathrm{~mm} \mathrm{Hg}\right)$ gave a distillate, which was washed with water to remove most of the TG. The aqueous layer was extracted with Skelly B. The Skelly B was removed by rotary evaporation and the residue combined with the organic layer. GLPC analysis indicated a mixture of $\mathrm{CFBr}_{3}$, diene and triglyme. A sample of pure diene was collected by GLPC for spectroscopic analysis. ${ }^{19} \mathrm{~F}$ - NMR (ppm, neat): $\delta-81.5\left(\mathrm{tm},{ }^{4} J_{\mathrm{FF}}=9 \mathrm{~Hz}\right),-101.0\left(\mathrm{dm},{ }^{3} J_{\mathrm{FF}}=136 \mathrm{~Hz}\right),-116.1$ (broad s), -121.4 (dm, partially overlapped, $\left.{ }^{3} J_{\mathrm{FF}}=136 \mathrm{~Hz}\right),-122.4(\mathrm{~s}),-123.0$ (s), -123.8 (m), 126.6 (s), $-152.7\left(\mathrm{dm},{ }^{3} J_{\mathrm{FF}}=138 \mathrm{~Hz}\right),-154.2\left(\mathrm{dm},{ }^{3} J_{\mathrm{FF}}=138 \mathrm{~Hz}\right)$. GC/MS, $\mathrm{m} / \mathrm{z}$ (relative intensity): 255 (98.6, $\left.{ }^{81} \mathrm{BrM}-\mathrm{C}_{5} \mathrm{~F}_{11}\right), 253\left(100,{ }^{79} \mathrm{BrM}-\mathrm{C}_{5} \mathrm{~F}_{11}\right)$.

4-dibromofluoromethyltetrafluoropyridine. $\mathrm{Ph}_{3} \mathrm{P}$ (9.4 g, $\left.35.8 \mathrm{mmol}\right), 35 \mathrm{ml}$ triglyme, $\mathrm{CFBr}_{3}$ (9.7 g, $36 \mathrm{mmol})$ and pentafluoropyridine (2.03 g, $12 \mathrm{mmol})$ were stirred at RT for 2 days; then distilled under vacuum. The first fraction $(2 \mathrm{ml})$ contained mostly $\mathrm{CFBr}_{3}$. The second fraction ( $\sim 25 \mathrm{ml}$ ) contained 4-dibromofluoromethyltetrafluoropyridine and triglyme. The second fraction was washed with a large excess of water to remove triglyme. The lower layer was saved; the aqueous layer was extracted with 2 x $16 \mathrm{ml}$ Skelly B. The Skelly B was removed by rotary evaporation; the residue combined with the organic layer; the combined material dried over $4 \AA$ molecular sieves, filtered, and redistilled to give $2.30 \mathrm{~g} \quad$ (56\%) of 4dibromofluoromethyltetrafluoropyridine, bp $40{ }^{\circ} \mathrm{C} / 0.5 \mathrm{~mm} \mathrm{Hg} .{ }^{19} \mathrm{~F}-\mathrm{NMR}$ (ppm, neat): $\delta$-59.1 (t, $\left.{ }^{4} J_{\mathrm{FF}}=45 \mathrm{~Hz}, 1 \mathrm{~F}\right),-88.7$ (m, 2F), -138.9 (m, 2F). GC/MS, m/z (relative intensity): 343 (2.4, ${ }^{81} \mathrm{Br}^{81} \mathrm{BrM}$ ), 341 (4.3, $\left.{ }^{81} \mathrm{Br}^{79} \mathrm{BrM}\right), 339$, (2.4, $\left.{ }^{79} \mathrm{Br}^{79} \mathrm{BrM}\right), 262$ (63.3, M-Br), 260 (66.4, M-Br), 201 (100, $\left.\mathrm{C}_{6} \mathrm{HF}_{6} \mathrm{~N}\right)$. HRMS: Calc'd for $\mathrm{C}_{6}{ }^{81} \mathrm{Br}^{79} \mathrm{BrF}_{5}$ : 342.8277, observed: 342.8301; Calc'd for $\mathrm{C}_{6}{ }^{81} \mathrm{Br}^{79} \mathrm{BrF}_{5}$ : 340.8297, observed: 340.8301; Calc'd for $\mathrm{C}_{6}{ }^{79} \mathrm{Br}^{79} \mathrm{BrF}_{5}$ : 338.8318, observed: 338.8325.

A sample of 4-dibromofluoromethyltetrafluoropyridine passed through a 20\% SE-30 GLPC column $\left(200^{\circ} \mathrm{C}, 30\right.$ minutes retention time) produced white crystals at the exit port. These were collected and analyzed by GC/MS and ${ }^{19} \mathrm{~F}$ NMR spectroscopy. ${ }^{19} \mathrm{~F}-\mathrm{NMR}$ (ppm, $\mathrm{CDCl}_{3}$ ): d -87.3 (m), 4F), -136.9 (m, 4F), -138.6 (m, 2F). GC/MS, m/z (relative intensity): 363 (0.6, M+1), 362 (3.6, M), $138\left(19.7, \mathrm{C}_{4} \mathrm{~F}_{4} \mathrm{~N}\right), 123\left(100, \mathrm{~N}_{2} \mathrm{~F}_{5}\right)$. This material is consistent with the structure: 


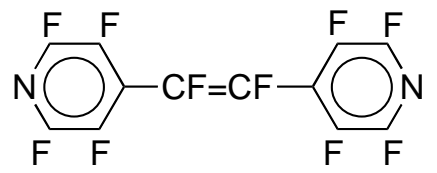

\section{Acknowledgements}

This work was supported by the National Science Foundation.

\section{References and Notes}

1. Chambers, R. D.; Mobbs, R. H. In Advances in Fluorine Chemistry, Tatlow, J. C.; Sharpe, A. G. Eds.; Butterworth: Washington, 1965; Vol 4, pp 50-112.

2. Chambers, R. D. Fluorine in Organic Chemistry; Blackwell: Oxford, 2004, Ch. 7, pp 162235.

3. Rozov, L. A.; Zeifman, Yu. V.; Gambaryan, N. P.; Cherburkov, Yu. A.; Knunyants, I. L. Izv. Akad. Nauk, SSSR, Ser Khim. 1976, 2750.

4. Burton, D. J.; Lee, T. M. J. Fluorine Chem. 1976, 8, 189.

5. Shaw, G. S. Ph.D. Thesis, University of Iowa, 1981.

6. Headley, J. A. Ph.D. Thesis, University of Iowa, 1975.

7. Burton, D. J.; Inouye, Y.; Headley, J. A. J. Am. Chem. Soc. 1980, 102, 3980.

8. Wheaton, G. A.; Burton, D. J. J. Org. Chem. 1978, 43, 2643.

9. Kesling, H. S.; Burton, D. J. Tet. Letts.1973, 39, 3355.

10. Burton, D. J.; Hahnfeld, J. L. J. Org. Chem. 1977, 42, 828.

11. Burton, D. J.; Yang, Z. Y.; Qiu, W. Chemistry Reviews 1996, 5, 1641.

12. Van Hamme, M. J. Ph.D. Thesis, University of Iowa, 1974.

13. Vander Haar, R. W., Jr, Ph.D. Thesis, University of Iowa, 1973.

14. Kimperhaus, W.; Buddrus, J. Chem Ber.1976, 109, 2370.

15. Flynn, R. M.; Manning, R. G.; Kessler, R. H.; Burton, D. J.; Hansen, S. W. J. Fluorine Chem. 1981, 18, 525.

16. Burton, D. J.; Flynn, R. M.; Manning, R. G.; Kessler, R. H. J. Fluorine Chem. 1982, 21, 371.

17. Hine, J. Divalent Carbon; Ronald Press: New York, 1964, Ch. 3, pp 36-65.

18. $\left({ }^{19} \mathrm{~F}\right.$ NMR yield) of $(\mathrm{Z})-\mathrm{CFBr}_{2} \mathrm{CF}=\mathrm{C}(\mathrm{Ph}) \mathrm{CF}_{3}$ was observed.

19. $\mathrm{Ph}_{3} \mathrm{P}$ : (7) was utilized in this work, since it reacts only with the most reactive fluoroolefins. $\left(\mathrm{Me}_{2} \mathrm{~N}\right)_{3} \mathrm{P}$ reacts rapidly with many fluoroolefins.

20. Howells, M. A.; Howells, R. D.; Baenziger, N. C.; Burton, D. J. J. Am. Chem. Soc.1973, 95, 5366.

21. If $\mathrm{CFBr}_{2} \mathrm{CF}_{2} \mathrm{CF}=\mathrm{CF}\left(\mathrm{CF}_{2}\right)_{3} \mathrm{CF}_{3}$ was formed in the addition-elimination reaction with $\mathrm{Ph}_{3} \mathrm{P}$ : and $\mathrm{CFBr}_{3}$, it would yield the same product. 
22. Zhang, X.; Lu, L.; Burton, D. J. Collect. Czech. Chem. Comm. 2002, 67, 1247.

23. Green, M.; Mayne, N.; Stone, F. G. A. J. Chem. Soc. (A), 1968, 902.

24. Pedersen, S. D. Ph.D. Thesis, University of Iowa, 1996.

25. Herkes, F. E.; Burton, D. J. J. Org. Chem. 1967, 32, 1311.

26. Burton, D. J.; Herkes, F. E. J. Org. Chem. 1968, 33, 1854.

27. LaZerte, J. D.; Hals, L. J.; Reid, T. S.; Smith, G. H. J. Am. Chem. Soc. 1953, 75, 4525.

28. Birchall, J.; Haszeldine, R. N. J. Chem. Soc. 1959, 13. 